\title{
Past, present, and future of Child Psychiatry in Mexico
}

\author{
Emmanuel Isaías Sarmiento Hernández, ${ }^{1}$ Patricia Zavaleta Ramírez, ${ }^{2}$ Armida Granados Rojas ${ }^{3}$
}

Dirección, Hospital Psiquiátrico Infantil Dr. Juan N. Navarro, Ciudad de México, México.

2 División de Investigación, Hospital Psiquiátrico Infantil Dr. Juan N. Navarro, Ciudad de México, México.

${ }^{3}$ División de Enseñanza y Capacitación, Hospital Psiquiátrico Infantil Dr. Juan N. Navarro, Ciudad de México, México.

\section{Correspondence:}

Emmanuel Isaías Sarmiento Hernández

Hospital Psiquiátrico Infantil Dr. Juan

N. Navarro.

Av. Sanbuenaventura 86

Col. Belisario Domínguez,

Tlalpan, 14080,

Ciudad de México, México.

Phone: 55 5573-4844

Email: emmanuel.sarmiento@salud. gob.mx

Citation:

Sarmiento Hernández, E. I., Zavaleta Ramírez, P., \& Granados Rojas, A. (2022). Past, present, and future of Child Psychiatry in Mexico. Salud Mental, 45(1), 1-2.

DOI: $10.17711 /$ SM.0185-3325.2022.001

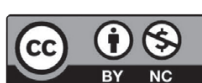

\section{INTRODUCTION}

The period between 0 and 18 years of age, childhood and adolescence, is the stage when children and adolescents have the best opportunity to grow, develop, and become healthy and productive adults. It is known that during this stage, children are exposed to multiple biological, psychological, and social influences which can become risky or protective factors for physical and mental health (Pérez-Cuevas \& Muñoz-Hernández, 2014). According to the World Health Organization (WHO), one half of the mental disorders begin before to 14 years old (Kessler et al., 2007) and from these only $20 \%$ are identified and receive mental health care (Neves \& Leanza, 2014).

Despite the fact that the WHO has recommended to its member countries that adequate services should be established for the care of children and adolescents with mental health disorders, in most countries the demand for children mental health care continues exceeding the resources available (Belfer, 2008).

\section{CHILD MENTAL HEALTH IN MEXICO}

\section{Past}

On September 1st, 1910, the mental hospital La Castañeda was inaugurated in Mexico City, which had 25 buildings with a capacity for 1,500 patients. It was thought that with this institution, Mexico would be at the same level of the most important countries in the treatment of mental illnesses (Escotto-Morett, Ángeles-Llerenas, Domínguez-Esponda, \& Márquez-Caraveo, 2017). However, for many years this vision only included the adult population, since the children and adolescents who entered the hospital shared the same spaces with adults. It was not until 1932 with the initiative of doctor Samuel Ramírez Moreno and doctor Mathilde Ruiz Cabo that the Children Pavilion was created in La Castañeda, a turning point that responded to the movement occurring in the Western world for the rights of the child population (Sosenski \& Sosenski, 2010); this formally begun Child Psychiatry in our country. However, after some years of starting this great project, on June 28, 1968, the closure of the mental hospital La Castañeda was announced and it brought about the relocation of 2,906 patients. A total of 102 children and adolescents were admitted to the Children's Psychiatric Hospital Dr. Juan N. Navarro (Hospital Psiquiátrico Infantil Dr. Juan N. Navarro, HPIJNN), inaugurated two years earlier (Márquez-Caraveo, Arroyo-García, Granados-Rojas, \& Ángeles-Llerenas, 2017).

\section{Present}

According to data from the Pan American Health Organization (PAHO), child and adolescent psychiatrists are still a very scarce human resource, with a regional median equal to or less than .04 per 100,000 inhabitants, which is similar to other regions in the world (PAHO, 2018). 
In Mexico, the Children's Psychiatric Hospital Dr. Juan N. Navarro has been the national benchmark not only for the care of children and adolescents with mental health disorders and / or addictions, but also for the training of medical specialists in Child and Adolescence Psychiatry. In this sense and in order to train physicians in the area of children's mental health who could provide specialized care, the HPIJNN opened the Child and Adolescent Psychiatry residency program in 1972 (Márquez-Caraveo et al., 2017), having graduated up to date a total of 558 physicians (database of this hospital). These human resources have undoubtedly been essential to achieve the objective of providing attention to mental health disorders and addictions that affect the child and adolescent population in our country. Furthermore, from 2002 to date, other institutions as the University Hospital Dr. José Eleuterio González from the Autonomous University of Nuevo León (Universidad Autónoma de Nuevo León, UANL), the National Institute of Psychiatry Ramón de la Fuente Muñiz (Instituto Nacional de Psiquiatría Ramón de la Fuente Muñiz, INPRFM), the Mexican Social Security Institute (Instituto Mexicano del Seguro Social, IMSS), and the National Pediatric Institute (Instituto Nacional de Pediatría, INP) became clinical emplacements for the training of specialists in this area.

Despite this, Mexico is facing a serious lack of national coverage for mental health care and addictions of children and adolescents. It is calculated that 38.5 million children and adolescents from 0 to 17 years old reside in Mexico, which represents $30.8 \%$ of the total population (Instituto Nacional de Estadística y Geografía [INEGI], 2018) while the estimated total of specialists in Child and Adolescent Psychiatry in 2018 was 375 (Heinze, Bernard-Fuentes, Carmona-Huerta, Chapa, \& Guízar-Sánchez, 2019), and according to the data from the different institutions by 2021 , it did not exceed 600 .

\section{Future}

In Mexico, the human and financial resources allocated for mental health are scarce (Berenzon Gorn, Saavedra Solano, Medina-Mora Icaza, Aparicio Basaurí, \& Galván Reyes, 2013), therefore, in order to solve this problem, it is of the utmost importance to establish changes within public policy. So far it seems clear that to achieve this, the most viable path from a community perspective is summarized in three points:

1. It is urgent to increase the number of specialists in child and adolescent psychiatry, considering WHO recommendations.

2. More support for the continuous training of health workers at the first level of care is needed, as well as continuous monitoring of workers who have already been trained with programs such as mhGAP (PAHO, 2017) and other newly implemented programs such as tele-medicine programs, including tele-mentoring, thus reducing the wide gap between available resources and the wide need of services for the population.

3. More support and supervision in the field of basic science research is also needed to generate scientific knowledge that contributes to establishing the biopsychosocial bases to provide care and solutions to the main child and adolescent's mental health disorders and the development of community care models in our country.

\section{REFERENCES}

Belfer, M. L. (2008). A global perspective on child and adolescent mental health. Editorial. International Review of Psychiatry, 20(3), 215-216. doi: 10.1080/09540260802028967

Berenzon Gorn, S., Saavedra Solano, N., Medina-Mora Icaza, M. E., Aparicio Basaurí, V., \& Galván Reyes, J. (2013). Evaluación del sistema de salud mental en México: ¿hacia dónde encaminar la atención? Revista Panamericana de Salud Pública, 33(4), 252-258.

Escotto-Morett, J., Ángeles-Llerenas, A., Domínguez-Esponda, R., \& MárquezCaraveo, M. E. (2017). Procesos de atención a menores de 20 años en La Castañeda: evolución del concepto de infancia en psiquiatría. Salud Pública de México, 59(4), 468-476. doi: 10.21149/8520

Heinze, G., Bernard-Fuentes, N., Carmona-Huerta, J., Chapa, G. C., \& Guízar-Sánchez, D. P. (2019). Physicians specializing in psychiatry of Mexico: An update 2018. Salud Mental, 42(1), 13-23. doi: 10.17711/SM.0185-3325.2019.003

Instituto Nacional de Estadística y Geografía [INEGI]. (2018). Encuesta Nacional de la Dinámica Demográfica 2018. ENADID. Diseño conceptual. México: INEGI. Retrieved from https://www.inegi.org.mx/contenidos/programas/enadid/2018/ doc/dc_enadid18.pdf

Kessler, R. C., Angermeyer, M., Anthony, J. C., De Graaf, R., Demyttenaere, K., Gasquet, I., ... Üstün, T. B. (2007). Lifetime prevalence and age-of-onset distributions of mental disorders in the World Health Organization's World Mental Health Survey Initiative. World Psychiatry, 6(3), 168-176. Retrieved from https://www.ncbi.nlm.nih.gov/pmc/articles/PMC2174588/

Márquez-Caraveo, M. E., Arroyo-García, E., Granados-Rojas, A., \& ÁngelesLlerenas, A. (2017). Children's Psychiatric Hospital Dr. Juan N. Navarro: 50 years of attention to the mental health of children and adolescents in Mexico. Salud Pública de México, 59(4), 477-484. doi: 10.21149/8514

Neves, M. G., \& Leanza, F. (2014). Mood disorders in adolescents: Diagnosis, treatment, and suicide assessment in the primary care setting. Primary Care: Clinics in Office Practice, 41(3), 587-606. doi: 10.1016/j.pop.2014.05.008

Pan American Health Organization [PAHO]. (2017). mhGAP intervention guide for mental, neurological and substance use disorders in non-specialized health settings: mental health Gap Action Programme (mhGAP) version 2. Washington, D.C.: PAHO. Retrieved from https://iris.paho.org/ handle/10665.2/34071?locale-attribute $=$ en

Pan American Health Organization [PAHO]. (2018). Atlas of Mental Health of the Americas 2017. Washington, D.C.: PAHO. Retrieved from https://iris.paho.org/ handle/10665.2/49664

Pérez-Cuevas, R., \& Muñoz-Hernández, O. (2014). Importance of public health focused on childhood and adolescence in Mexico. Boletín Médico del Hospital Infantil de México,71(2),126-133.

Sosenski, S., \& Sosenski, G (2010). En defensa de los niños y las mujeres: un acercamiento a la vida de la psiquiatra Mathilde Rodríguez Cabo. Salud Mental, $33(1), 1-10$. 